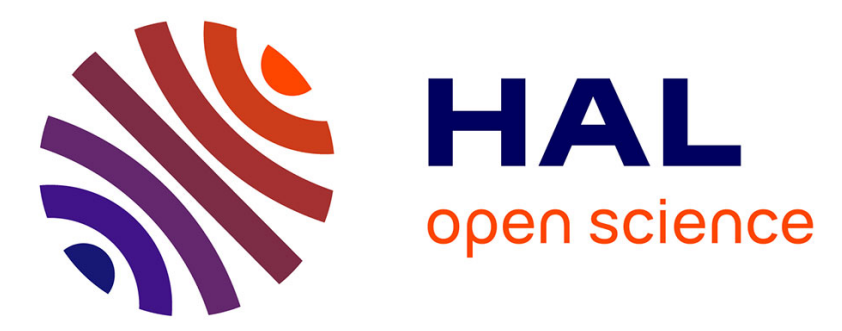

\title{
Inter-library loan services and access to electronic resources in French university libraries: a marriage of reason
}

Chérifa Boukacem

\section{To cite this version:}

Chérifa Boukacem. Inter-library loan services and access to electronic resources in French university libraries: a marriage of reason. Interlending and Document Supply, 2003, 31 (4). sic_00000946

\section{HAL Id: sic 00000946 \\ https://archivesic.ccsd.cnrs.fr/sic_00000946}

Submitted on 19 Mar 2004

HAL is a multi-disciplinary open access archive for the deposit and dissemination of scientific research documents, whether they are published or not. The documents may come from teaching and research institutions in France or abroad, or from public or private research centers.
L'archive ouverte pluridisciplinaire HAL, est destinée au dépôt et à la diffusion de documents scientifiques de niveau recherche, publiés ou non, émanant des établissements d'enseignement et de recherche français ou étrangers, des laboratoires publics ou privés. 


\title{
Inter-library loan services and access to electronic resources in French university libraries : a marriage of reason
}

\author{
Chérifa BOUKACEM \\ Cboukace@enssib.fr \\ GRESI : Groupe de REcherche sur les Services d'Information \\ Enssib, 17-21 Bd. du 11 novembre 1918, 69623 Villeurbanne Cedex 09
}

\begin{abstract}
This article uses the results of a thesis to analyse the changing structure of access services to scientific and technical information in French university libraries, and corresponding changes in the role of Inter-Library Loan services. These changes have mainly occurred with the growing integration of electronic resources in collections and an overhaul of the services on offer. Given the specific features of access systems to scientific information and the wide range of users in the various sections of university libraries, we will be attempting a detailed analysis of the situation in the French university network.
\end{abstract}

Key words : inter-library loan, document supply, university libraries, electronic resources.

\section{Introduction}

Among the many perspectives opened up by the advent of the Internet, on-line access to the full text of scientific and technical information (STI) has been the most directly relevant to university libraries. Scientific information should be taken here as referring to published - and therefore peer-reviewed - information. The university libraries have become well aware of the potential of the new information media to improve their STI access services, which had essentially been of two types: inter-library loans (ILL) and document supply (DS), both provided by the same university library department and known as the Inter-Library Loans service. The rapid expansion of on-line electronic document supply services from commercial scientific publishers naturally raised questions as to the long-term perspectives of library services that were based on paper documents. Given the specific requirements of users in the various fields, this study attempts to answer the question of the long-term viability of traditional ILL and DS services within the French university network.

\section{Framework for an analysis of nationwide trends}

The network that circulates STI in France involves two main bodies, the Institute for Scientific and Technical Information (INIST - Institut de 1'Information Scientifique et Technique $)^{1}$ and the national university libraries network. Our article focuses on the distribution of documents within the latter, which is made up of 96 libraries. For administrative purposes, these are organised into four sections, each of which covers certain disciplines:

- Science, Technology (ST);

- Health (federation of medical disciplines);

- Arts, Humanities and Social Sciences (AHSS);

- Law, Economics and Management (LEM).

\footnotetext{
${ }^{1}$ - The author expresses thanks and gratitude to Joachim Shöpfel, INIST'S head librarian, for discussions and reflections leading to the outcome of this article.
} 
In France, a general statistical survey of university libraries (Enquête Statistique Générale des Bibliothèques Universitaires or ESGBU) has been sent out each year since 1975 to the university libraries, to collect data on their facilities and the services they provide, including ILL activities. An executive summary of the data for each university library is produced in tabular form by the Libraries Sub-directorate of the Ministry for Higher Education. The data have been published as a statistical directory of university libraries since 1988. An interactive statistics application for university libraries (ASIBU) is available at the following Web address: http://fermi2.sup.education.fr/asibu/

Using the data collected through the ESGBU, we produced a graph for the period from 1975 to 2000 , showing variations in flows of incoming and outgoing requests handled by the library network. In both cases, the figures cover both physical loans (ILL) and the supply of document copies (DS) and therefore do not show their respective proportions.

Figure 1 summarises the results obtained. The form in which these data are represented is entirely new and lies at the core of our discussion.

Figure 1 : Nationwide variation in natiowide ILL and DS flows, 1975 - 2000

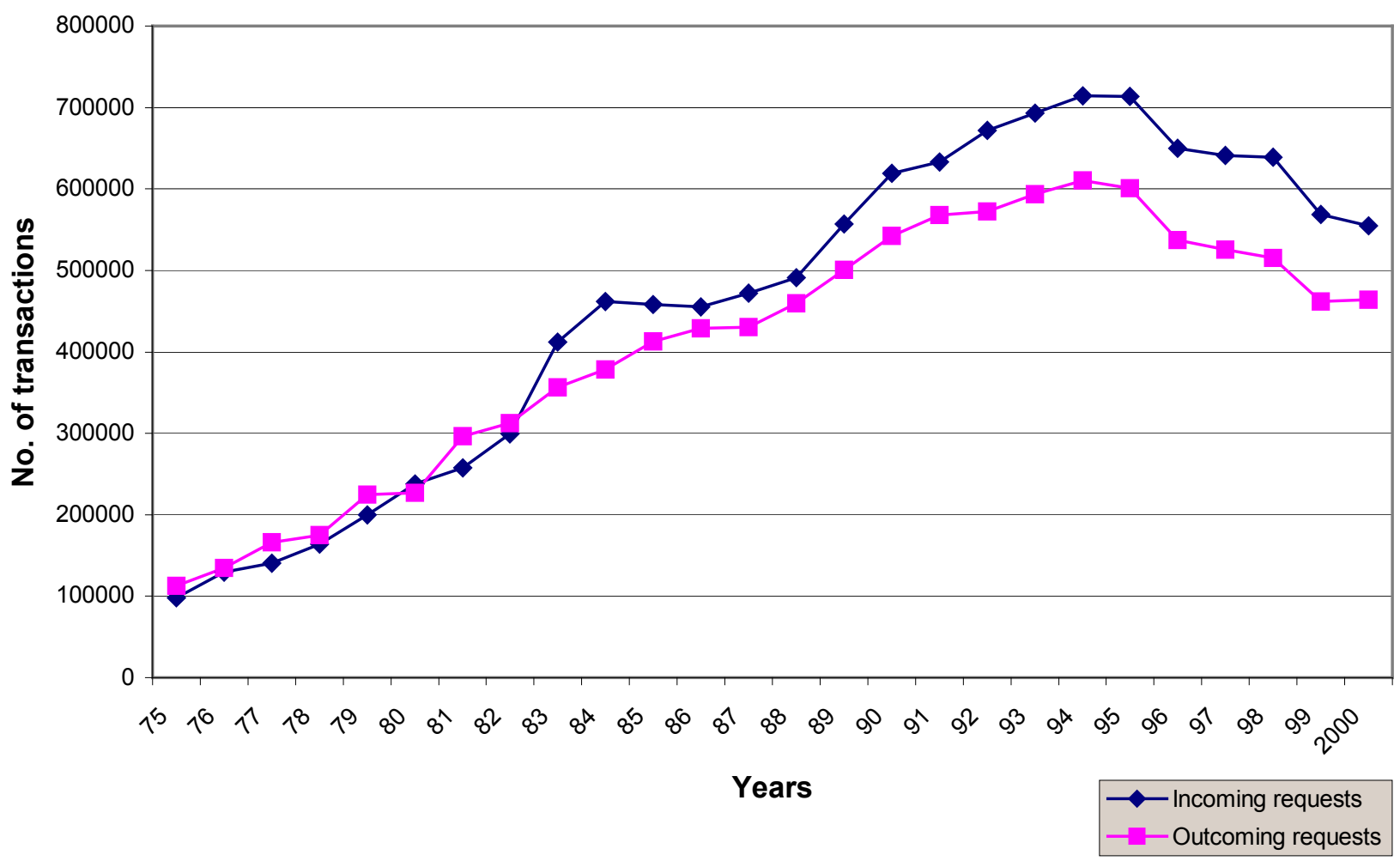

The graph gives an overall picture of trends over the last 25 years, for all sections and disciplines and for both incoming and outgoing requests. This proved particularly useful to gain insights into the impact of developments that affected university libraries during the period. The comments and analyses we will be making are therefore relevant to inter-library loan services in all disciplines, but our analysis of quantitative data alone did not provide enough material to cover the subject fully and provide answers to all the questions raised. This is why we also used a qualitative method of a different type to bring our figures into perspective. The second method involved over forty semi-directive interviews during the year 2000 among university libraries Head Librarians, ILL department heads, librarians and information professionals. The sample was made up of university libraries with and without 
CADIST status (Centres for acquisition and distribution of scientific and technical information) specialising in the sections mentioned above. For our overall analysis of Figure 1 , we have analysed the curve into three phases.

\subsection{Upward trends: 1975 - 1994}

Our analysis of this phase draws on perspectives in technology, economics and documentation.

\section{Technological and economic perspectives}

The trend over this period reflects the consolidation of information technologies which caused university libraries to organise cooperative efforts in the form of network infrastructure. Networked cataloguing through the OCLC (Online Computer Library Center) was one of the most obvious examples. Cooperation expanded rapidly and provided valuable support to libraries facing the difficulties of an economic context that was characterised by inadequate budgets and increasing documentation costs. These affected library acquisitions, so that cooperative efforts became essential to coordinate documentation policies. Acquisition and resource sharing networks as well as the French CADIST network (1980) were set up to meet the demands of the new situation. Libraries with especially rich or specialised collections sought CADIST recognition in order to become established as specialised document centres entitled to budget subsidies to acquire and distribute foreign scientific documentation. The CADIST system was the very first identifiable structure for sharing acquisitions, inter-library loans and document supply in France. The mutual and therefore interdependent linking of funds that resulted naturally helped to increase ILL and DS flows. In 1985, the Common Documentation Services (Services Communs de Documentation or SCD) were set up in addition to the existing structures to help remedy the dispersal of documents resulting from the fragmented organisation of campuses with their specialised university libraries and research units, which were often small laboratory libraries attached to different organisations to which they supplied documentation at research level. The SCDs operate under a policy for the coordination of documentation activities (which may include inter-library loans) and make particular efforts to establish mutual acquisition budgets.

\section{Perspectives in documentation}

The constant and rapid increase in French ILL flows was encouraged and strengthened by various developments in documentation, such as the launch of the National Union Catalogue of serial publications (Catalogue Collectif National des Publications en Série or CCNPS) in 1983, the Pancatalogue (Union Catalogue of monographs) in 1989, the Union Catalogue of doctoral theses on CD-Rom (Télé-Thèses) and the Peb-Net ILL messaging service in 1992. All these products helped to boost inter-library loan services. In addition, the increasingly widespread availability of databases on CD-Rom or on line (Medline, Inspec, Pascal, etc.) were of considerable help in publicising the existence of documentation that was not available within particular libraries but had become accessible through document supply services. Furthermore, prices for on-line database searches dropped during the period. The sector therefore continued to grow with increasingly broad database availability and greater flexibility for users thanks to new client-server technology. 


\subsection{Downward trends: 1994 - 1999}

Our analysis of this phase reflects an economic and technological context whose repercussions on the operations of the French network opened up completely new possibilities for the future.

\section{Economic and technological perspectives}

The nationwide fall in ILL and DS flows occurred at a significant time for the French university network. 1994-1995 was the period when the Internet was officially introduced into French university libraries. Commercial publishers were quick to offer electronic resources such as serial publications, electronic versions of printed periodicals or completely new electronic journals. These were available free of charge to begin with, in order to create a demand prior to large-scale development, but fees were introduced later [CHAR98]. Most products were in the areas of science, technology and health, so users from these fields were the first to take an interest. This signalled a move away from traditional ILL services, which were considered too slow and costly, and towards fast, direct, non-paying access. All these factors help to explain the success of the Web and its resources and also account for the countrywide drop in ILL activities.

A further economic factor accentuated the decline. Library loans had been free of charge until 1996, when a postal charge of $50 \mathrm{FF}$ per item was introduced. This was a significant amount for users whose documentation is not always funded by their research laboratories. The impact seems to have been greatest in the AHSS and LEM sections. At the same time, document supply prices increased from 20 to $32 \mathrm{FF}$ for the first ten article pages and from 10 to $16 \mathrm{FF}$ for subsequent batches of ten pages. These price increases also account for the decline in ILL services.

\section{Repercussions on documentation patterns in the university libraries network}

Our interviews showed that the university libraries preferred to centralise the shipping of requests through a single supplier, to save time and money and improve efficiency. Prices rises were not uniform among the university libraries. The CADIST libraries, whose core mission is document distribution, soon became the primary targets for requests. Since ILL activities began to decline, document flows have tended to concentrate on a small number of libraries, usually those in the CADIST network. This development has become a characteristic of document circulation within the French system and is apparent both in ESGBU figures and in the results of the interviews we conducted in the different sections.

Figure 2 below shows the proportion of incoming requests sent to the five university libraries supplying the most documents in each academic discipline, compared to the rest of the system. All five are CADIST members. The increasing concentration of flows since the early 1990s ran counter to the objectives of CADIST libraries, which are supposed to be final backup resources, and to the efforts of the SCD. 


\section{Proportion of incoming requests (2000)}

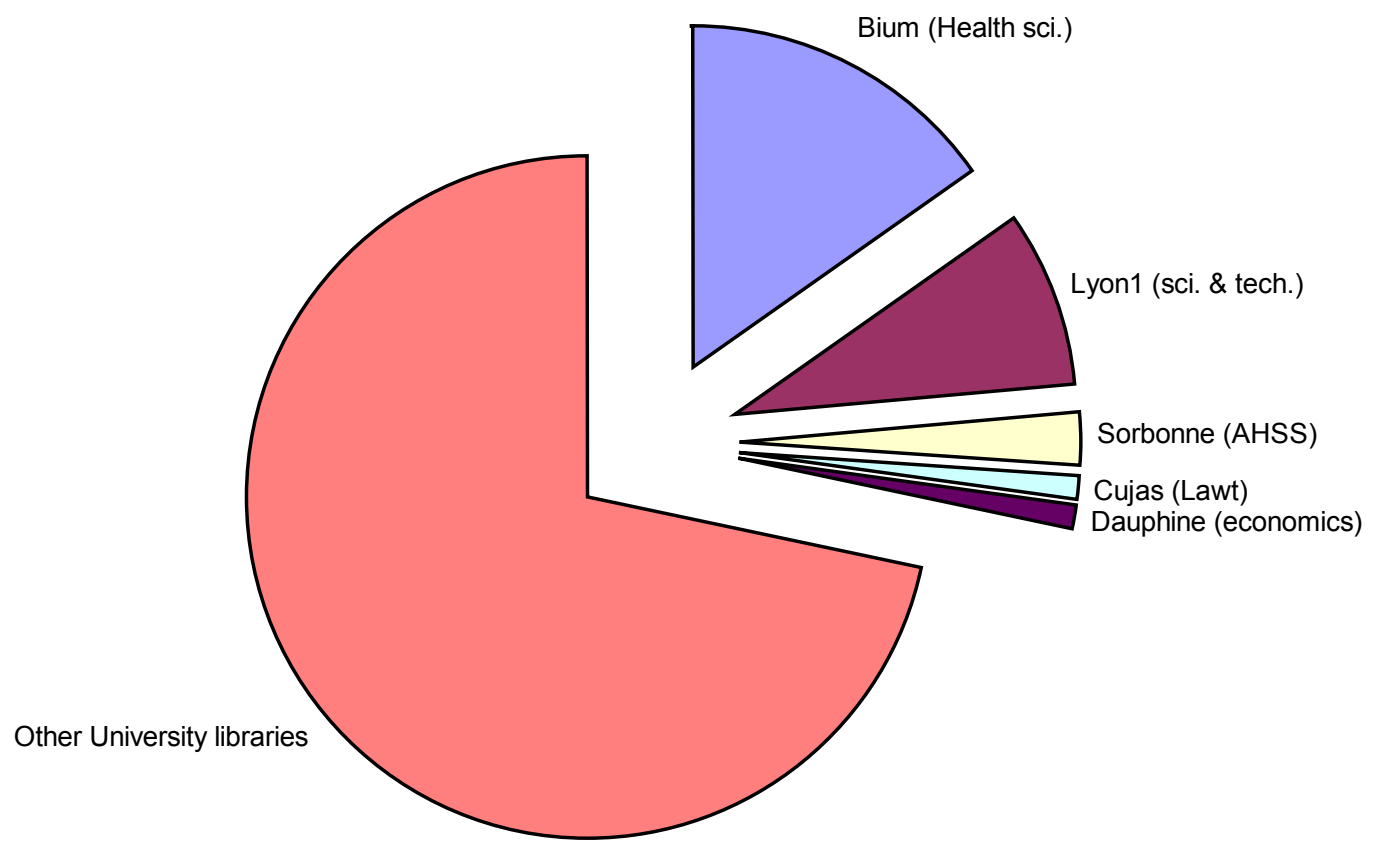

\subsection{0: A new upward trend?}

ESGBU figures for the year 2000 (Figure 1) show that after a five-year decline (1995-1999), the number of requests (for loans and document copies) increased by $1 \%$ over the previous year (5050 additional requests). This increase is too recent and too small to be interpreted conclusively and may either continue or level out. This development needs to be seen in the context of the launch, on 1 June 1999, of the COUPERIN consortium for digital serial publications (Consortium Universitaire de PERIodiques numériques, www.couperin.org). The increase observed in 2000 therefore probably stems from the broader range of documentation and document services that became available to the university libraries through the COUPERIN system.

The situation was affected in two ways: first, with over 1700 electronic serial publications on offer, university libraries redefined their documentation policies and had to come to terms with the coexistence of paper and electronic documents in a hybrid environment. University libraries receive a $60 \%$ subsidy in their first year and $40 \%$ in the two subsequent years from the Libraries Sub-Directorate, and have to call on their university and research units (INSERM, CNRS, etc.) for co-funding to cover the additional costs of electronic documentation. Valuable work was carried out by the SCD in the run-up to the launch of COUPERIN, which in turn accentuated the imperatives and objectives of the SCD: whereas the gap in the quality of university library collections based on printed material widened between CADIST and other libraries and between Parisian and provincial university libraries, COUPERIN's efforts are tending to redress the balance.

The quantitative study conducted by Thomas Sanville for the consortium at the OhioLINK Journal Center [SANV01] has produced a double histogramme showing that libraries with the 
smallest collections of printed material began to catch up with other libraries as regards the consultation of electronic serial publications, with the number of searches increasing with the degree of openness of access points. The introduction of COUPERIN is therefore likely to create a similar trend in French university libraries, but this cannot be confirmed as yet, as the required statistics are not available.

The second change brought about by the COUPERIN system was a shift to multidisciplinary document searches. COUPERIN was not the first stage in the integration of documentation within universities. The first groups were thematic and operated locally, on the scale of a campus as in Nice, or of a city as in Aix-Marseille (for Science Citation Index) [FRES99]. The impact of the consortium is therefore based on its multidisciplinary and nationwide approach. It has strengthened core collections in university libraries and added material in marginal disciplines. Users became aware of a hitherto unknown source of documentation that could also provide links to references that were only available in print form in other university libraries. Our interviews revealed that users were making interdisciplinary and retrospective searches, an aspect that was strengthened by the implementation of the University Documentation System (Système Universitaire de documentation or SUDoc). The Union Catalogue was the result of a merger between the three union catalogues mentioned earlier, and has been freely available for consultation through a Web interface since 1999.

Supporting our hypotheses on the likely direction of future trends, the latest ESGBU figures (2000) show that the volume of document loan and supply transactions has been shared out over a larger number of university libraries, with $80 \%$ of requests processed by $34 \%$ of libraries (as against $30 \%$ in 1999) [ANNU00]. Moreover, given the increase in the number of incoming requests, we have made the assumption that this observed trend is likely to spread to other sections and to continue over time.

However, as stated previously, Figure 1 shows the flows of incoming and outgoing ILL and DS requests in all disciplines. Overall interpretations and explanations would therefore be rather risky and we will be refining our analysis in the next part of the article by looking at the figures for each discipline.

\section{Analysis of trends by section}

PebNet, the French ILL messaging service and integrated management application implemented by the Bibliographic Agency for Higher Education (Agence Bibliographique de l'Enseignement Supérieur or ABES) links up all university libraries. The PebNet statistics module provides accounts of all incoming and outgoing requests recorded by the university libraries per section. The ABES, to which we would like to extend our thanks here, has agreed to provide us with the relevant data, which we have used to build up the figures showing trends in the activities of ILL services within each section. The data only cover the period from 1994 to 1999, but have been of great help to refine our interpretations.

\subsection{Focus on the science, technology and health sciences sections}

\section{Parallel trends nationwide and by section}


The following describes variations in the activities of ILL services in the scientific and technological sections (Figure 3) and the health sciences sections (Figure 4). Like figure 1, these graphs show that the drop in ILL flows in these sections has followed the national pattern.

Figure 3 : Variation in ILL and DS flows in Sciences and Technology sections

(1994-99)

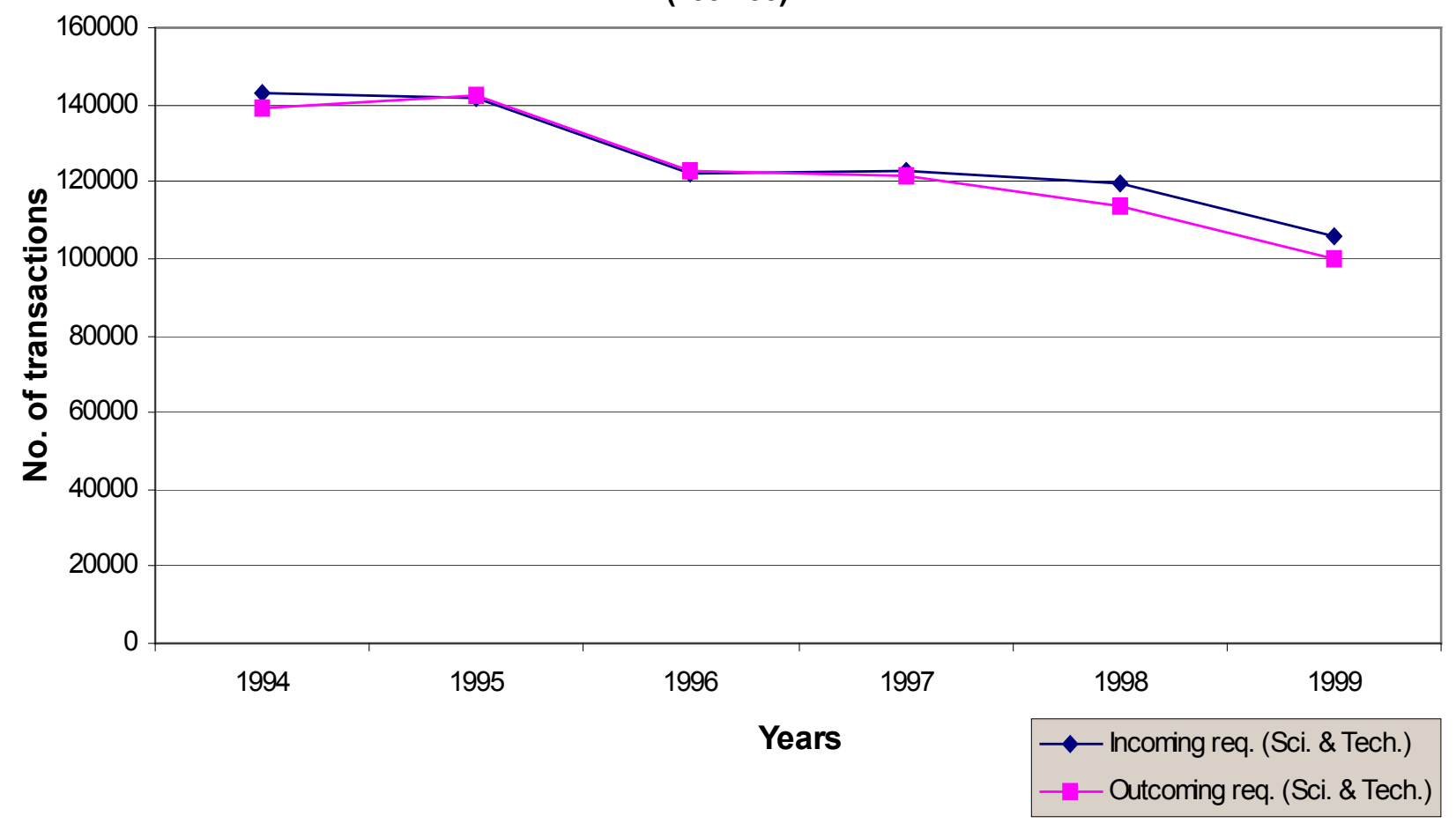


The interviews we conducted show that the same criteria explain the drop in both sections. ILL services in these sections account for some of the largest volumes in the university library system, with journal articles as the main medium for STI distribution. The significant decline in flows in these sections, mainly due to falling DS requests, has therefore been largely responsible for the nationwide decline and has resulted from the fact that emerging electronic resources were beginning to meet user expectations of fast access to scientific and technical information.

Figure 4 : Variation of ILL and Ds in health sciences sections (1994-99)

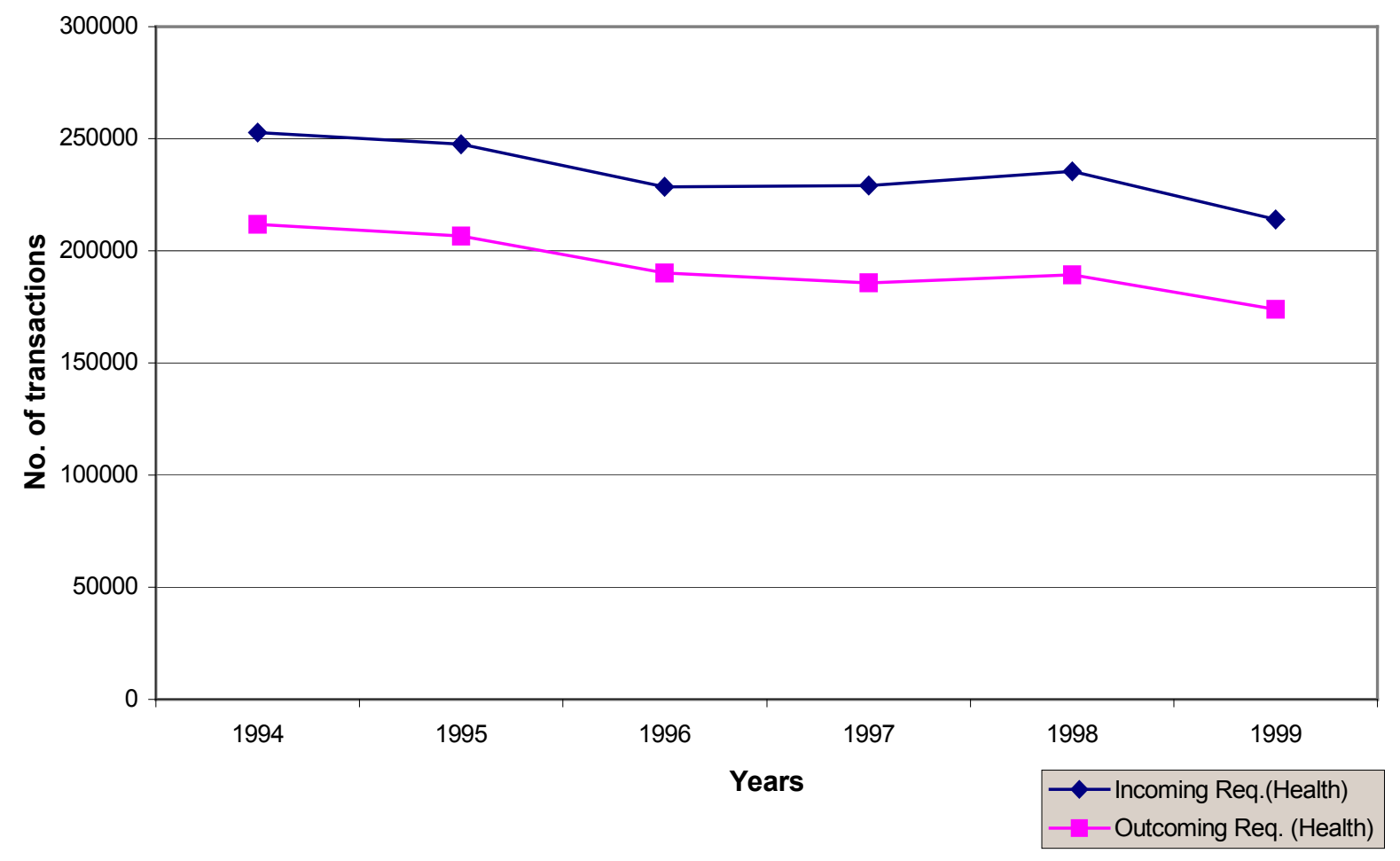

The range of available electronic documentation has become broader and better organised, attracting increasing numbers of users. Staff in ILL departments are devoting more time to training, information searches and web site implementation.

\section{The strengthening of COUPERIN has increased section potential}

More and more university libraries in these sections began to post up web sites to highlight the specific features and richness of their collections and services, targeting users who were becoming more varied, better informed and more demanding in terms of the skills they expected from library staff. As the structure of Web sites improved [VAND99], professionals were better able to point readers to print and on-line resources and provide user support. These professionals strongly emphasise the importance of gaining recognition for their new skills in assisting and supporting researchers.

The implementation of COUPERIN in 1999 strengthened the integrated use of electronic resources by broadening and improving the structure of the documentation on offer. The interviews conducted in these sections show that the perceived increase in outgoing library requests seems to parallel the nationwide increase illustrated above. At present, our interview results are the only indication of this increase, as no figures confirming the trend are available as yet. 
Our analysis suggests that COUPERIN appears to have encouraged retrospective bibliographic searches through multidisciplinary resources, as users have become more aware that they can access a broad, though not sufficiently exhaustive source of information. In large areas of scientific documentation, ILL and DS services thus remain the sole means of access that libraries can legally offer their users. Trends in the STM sections thus parallel those observed nationwide. It is tempting to argue, once again, that these sections are contributing to the upward trend we have identified as the start of a third phase, but we do not yet have the figures to confirm this.

\subsection{Focus on the Law, Economics and Management sections}

\section{An atypical pattern}

The pattern shown in Figure 5 runs counter to nationwide trends. The first phase (from 1994 to 1996) shows the decline we have attributed to the introduction of postal charges, as mentioned earlier, within a community where monographs were the main items of documentation requested.

Figure 5 : Variation of ILL and DS in LEM sections (1994-99)

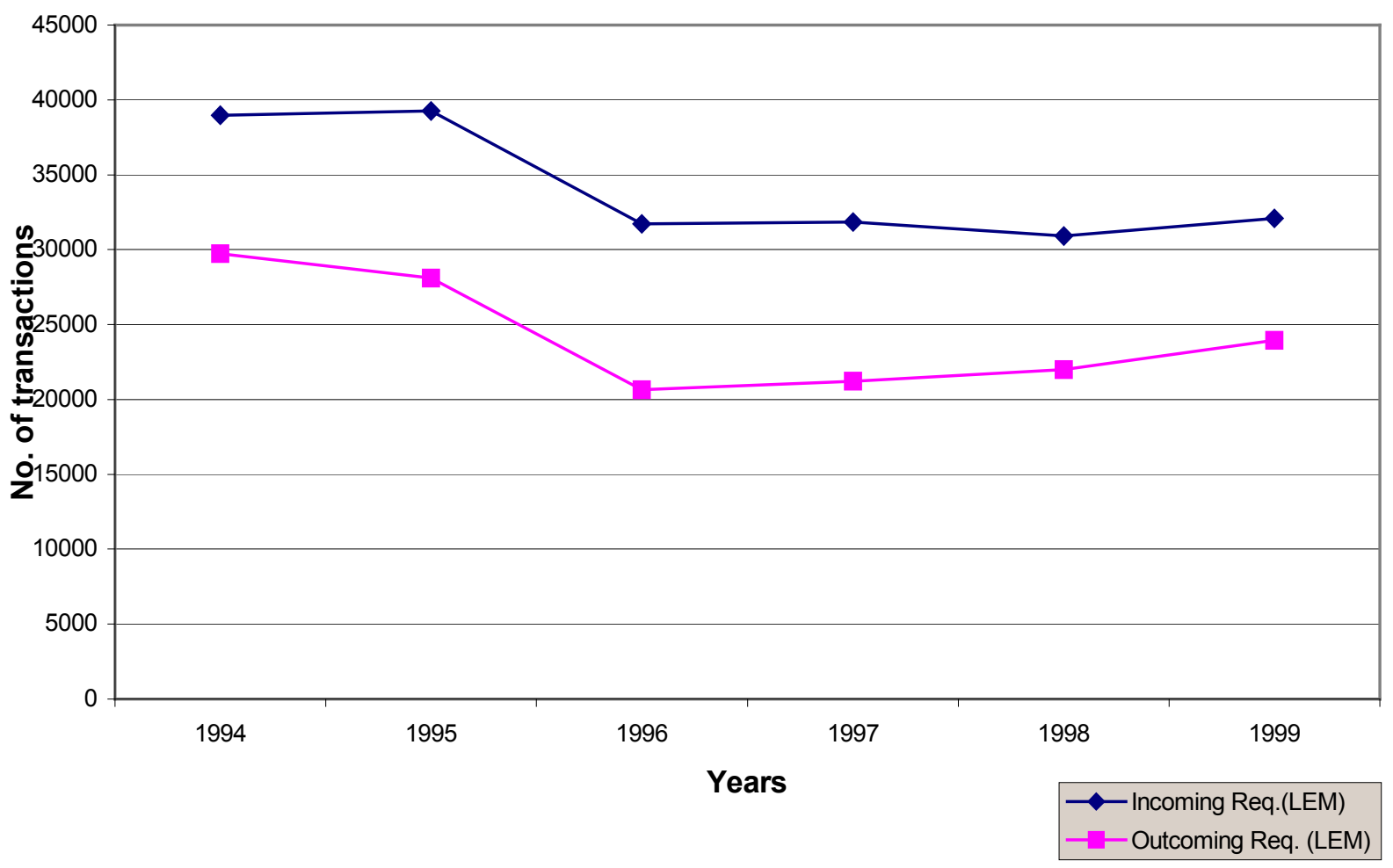

After 1996, the graph shows a perceptible and regular increase in the number of transactions. Our interviews in these sections suggest that this increase in flows concerns document supply services and is part of a shift stemming from needs that relate to database development. This upward trend has continued thanks to broader and less costly access to databases and the greater flexibility afforded by client-server technology. The increasing interest among researchers in on-line access to databases (e.g. Francis, MLA, Doc-Theses or EconLit) has been largely responsible for a growing awareness of sources of documentation that are often international and unavailable within libraries themselves but can increasingly be accessed in full text on line or through ILL services. 
Our interviews also showed that INIST (INstitut de l'Information Scientifique et Technique), as a document supplier, is less in evidence among university libraries specialising in Law, Economics and Management than among the STM libraries. Some university libraries in our LEM sample seized the opportunity provided by our survey to develop specific services geared to bibliographic research and document supply targeting a private clientele.

Users in the LEM sections still demonstrate a certain amount of reluctance which is symptomatic of a mismatch between on-line technology and their particular research habits [PERO02], although they know and appreciate messaging functions [PERO02], [MUET99] and are also familiar with the potential of the Internet for bibliographic research.

The university libraries web sites have been preparing for and accelerating the growth of Internet use. The CADIST libraries were the first to make progress in the area, thanks to a Web site which lists and publicises free electronic journals in the LEM disciplines, to promote their use among the research community. This was mainly an initiative from ILL managers, generally working in cooperation with subscription services.

Like those in the two sections described previously, the Web sites run by the university libraries are increasingly well organised. Examples are those run by the CADIST libraries at Cujas (Law) and Dauphine (Economics), where electronic resources are presented methodically and organised as specialised thematic portals. According to our interviewees, users most appreciate services provided in PUSH mode, which links up different sources of information on the same site.

\section{Impact of the COUPERIN system}

The Law, Economics and Management sections have been affected by the repercussions of the publishing crisis in STM fields, and to a lesser extent in LEM. The analysis of our interviews shows that the provincial LEM sections have sometimes reduced their expenditure on documentation to help the STM sections cope with price inflation.

This is why one of the most clearly stated concerns among our interviewees was to join a national consortium or found a thematic consortium of their own. Their arguments were based on economic considerations with a view to addressing the rising costs of documentation by federating resources and means. 2000 was the year when the expansion of on-line resources, thanks to the COUPERIN system, began to match the increase in demand.

Broader access to international bibliographic references, possibilities for retrospective and/or cross-referenced searches and data archiving, fast access and links between articles have brought unprecedented benefits to users. Among readers with the necessary equipment, direct access from the desktop is also much appreciated [PERO02]. Possibilities for access to the full text of journal articles have also boosted ILL and DS services: because search fields have broadened considerably, user demand has increased and become more interdisciplinary.

The time and money saved by users suggests that in the next few years, inter-library loan activities, which are still maintaining a balance with document supply services, are likely to decline with the growth of electronic access to full-text articles.

\subsection{Focus on the Arts, Humanities and Social Sciences sections}




\section{Disparities with national trends}

The prior statistical analysis carried out for the AHSS sections shows, in Figure 6, that variations in the national pattern are not reflected here. With the introduction of postal charges, AHSS loans declined more rapidly than in the LEM sections but levelled out with the payment of a subsidy by the Ministry.

Figure 6 : Variation of ILL and DS in AHSS sections (1994-99)

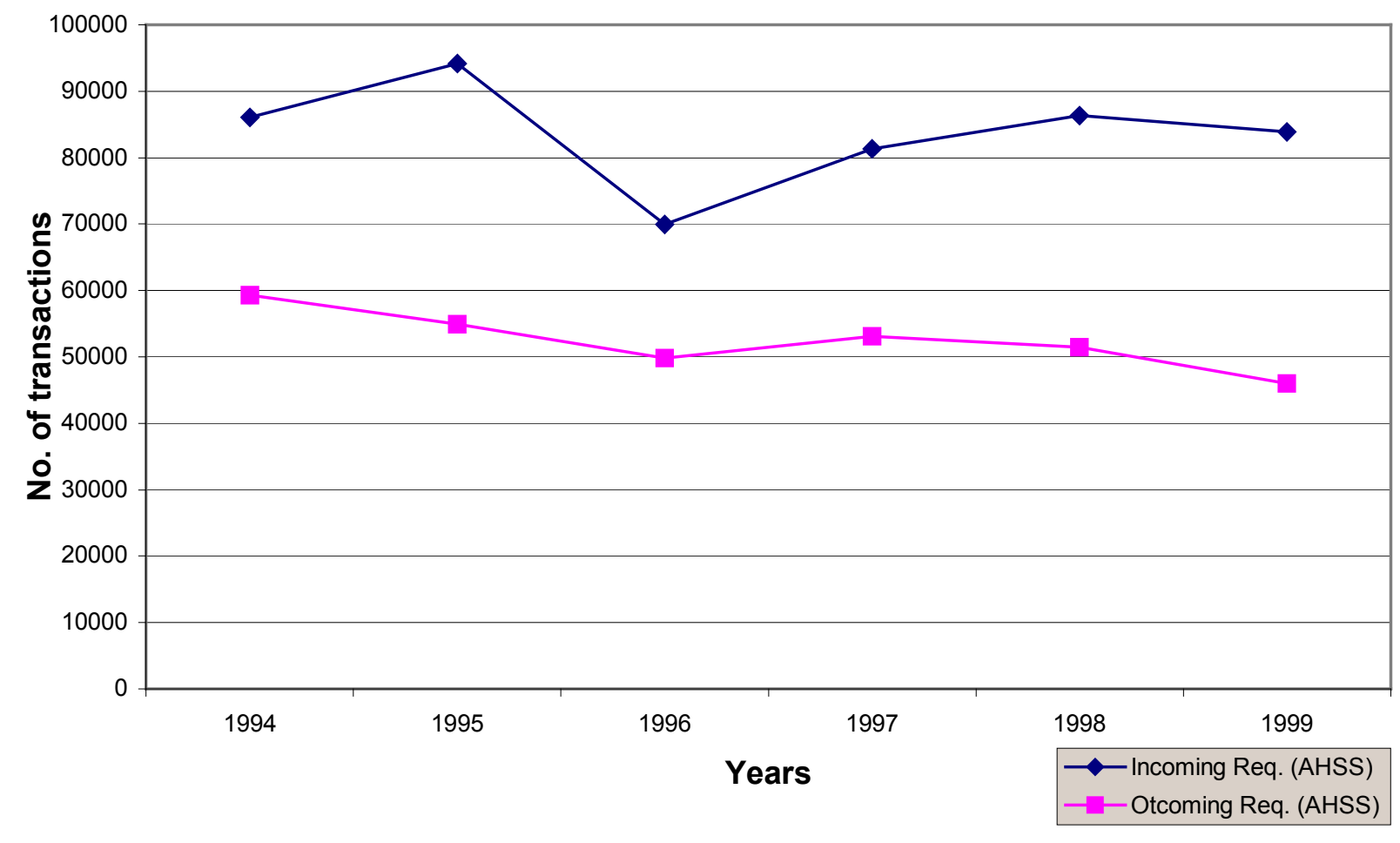

The interviews we conducted in the university and CADIST libraries highlighted two essential factors which help to explain the very slight impact of national trends on the Humanities and Social Sciences sections. First of all, user attitudes in the sections towards electronic resources are characterised by poor awareness, suspicion and reluctance, as borne out by studies conducted among the AHSS community [PERNO2]. The second factor is the modest availability of electronic resources likely to be of interest to this community.

The two factors are mutually reinforcing, as the inertia that characterises AHSS researcher habits is linked to poor visibility on the supply side and to the fact that scientific and technical information in this area has not reached a critical mass on the Web [CLEM00]. The lack of a dynamic supply side may be accounted for by the low level of interest among major commercial publishers for disciplines where the stakes are not high because of limited demand from researchers. The smaller publishers are lagging behind for want of sufficient means. The following figures [CLEM00] illustrate the dispersal and the wide gap between products on offer from large and small publishers:

$10 \%$ of publishers publish 40 to $50 \%$ of titles.

$70 \%$ of publishers only publish one title.

Legal aspects have also slowed down the development of on-line journal publication in this area. As underlined by Ghislaine Chartron [CHAR01], the requirement for prior permission 
from authors before their works can be posted on line can be a serious obstacle. Predictably, the AHSS journals available on line in the 1990s were not in as much demand as STM journals. Because of reluctance among readers and their lack of awareness of the products on offer, which in turn are not well publicised by libraries, the AHSS sections are unlikely to be affected by the major upheavals that have occurred in the STM sections.

\section{Towards electronic document supply?}

In the departments where we conducted our interviews, early collections are in regular demand. The interviews showed that librarians are keenly interested in digitising these collections to promote both document circulation and their own library's resources. Such early documents are not under copyright and the only obstacles to these projects have to do with staffing and equipment. However, of all ILL services, the AHSS sections are the most disadvantaged in these respects. The AHSS university libraries are gradually posting up catalogues of small digital collections on their Web sites, which are now available to the general public.

With the introduction in June 2000 of a statutory framework for the electronic deposit of academic theses in France, it is likely that the relevant departments will start circulating these documents on line. One consequence for professionals is that university libraries can now own their own information and production systems. A number of our interviewees had already begun discussions with a view to recovering the ownership of information which is mainly produced by and within universities but delivered to publishers who take over the copyright [OKRE00].

\section{Conclusion}

Figure 1 showed the beginnings of a decline in access to paper documentation in French university libraries, as access to on-line documentation grew. Our figures per section show that this was a relative trend and that the overall picture masks considerable variations between the various disciplines represented by each section. The analysis of our interviews also shows variations in the degree of integration of electronic resources within university library collections. This essentially stems from the unequal distribution of documentation available through the COUPERIN system, which is geared primarily to STM, and from the inertia - or potential for growth - among users of the different sections.

The shift towards hybrid collections means that access possibilities can be tailored to different user environments and needs. The coexistence of different means of document circulation and supply is complementary rather than redundant. A direct consequence of this is the trend which may become more marked - towards a more efficient distribution of document flows within the library system and a consequent boost to ILL and DS activities.

The increasingly hybrid collections within French university libraries has had another impact on user demand. Users now have access to multidisciplinary collections that enable them to broaden their search fields and bibliographic research. A direct result of this is a shift in demand, which is increasingly geared to multidisciplinarity. This suggests that ILL services in France are likely to focus increasingly on retrospective and interdisciplinary requests. Further studies would enable us to validate this assumption.

\section{Glossary}


- ABES: Higher Education Bibliographic Agency (Agence Bibliographique de l'Enseignement Supérieur).

- CADIST: Centre for Acquisitions and Distribution of Scientific and Technical Information (Centre d'acquisition et de Diffusion de l'Information Scientifique et Technique).

- COUPERIN: COnsortium Universitaire de PERiodiques Numériques.

- LEM: Law, Economics and Management.

- ESGBU: General Statistical Survey of University Libraries (Enquête Statistique Générale des Bibliothèques Universitaires).

- DS: Document Supply.

- STI: Scientific and Technical Information.

- AHSS: Arts, Humanities and Social Sciences.

- OCLC: Online Computer Library Center.

- ILL: Inter-Library Loan.

- SCD: Common Documentation Service (Service Commun de Documentation).

\section{Bibliography}

- [ANNU] Annuaire des bibliothèques Universitaires : Résultats de l'enquête statistique générale auprès des bibliothèques universitaires, $M E N R S-S D B, 1988$ - 2000.

- [BRIT01] Brito, Marcilio de, «Les périodiques francophones et les modèles numériques : une analyse comparative des indicateurs bibliographiques internationaux », 2001, http://isdn.enssib.fr

- [BROW96] Brown, David J.- Electronic publishing and libraries : planning for the impact and growth to 2003.- Bowker Saur, 1996.- 200 p.

- [CHAR98] Chartron, Ghislaine ; Marandin, Clarisse. - Presse scientifique électronique : Analyse de l'offre des intermédiaires, in: Bulletin des Bibliothèques de France, 1998, Vol. 43, No.3,pp. 28-40

- [CHAR00] Chartron, Ghislaine ; Salaün, Jean-Michel.- La reconstruction de l'économie politique des publications scientifiques, in : Bulletin des bibliothèques de France, 2000, No.2, t.45, pp.32-42

- [CHAR01] Chartron, Ghislaine, «L'information scientifique et le numérique », Mémoire d'habilitation à diriger des recherches, 2001

- [CLEM00] Clément, Caroline; Bonvin, Marc, «Les périodiques électroniques en sciences humaines et sociales : analyse de l'offre et test de catalogage sur VTLS à la bibliothèque de Lausanne-Dorigny », 2000, www.unil.ch/BCU/recherche/1 art bi.htm 
- [FRES99] Freshard, Chantal ; Okret, Chritine.- La documentation électronique : état des lieux et perspectives de développement dans les bibliothèques des établissements d'enseignement supérieur français, in : Bulletin des Bibliothèques de France, 1999, Vol.44, No.4, pp.62-65

- [GUIC01] Guichard, Eric, «Comprendre les usages de l'Internet», Presses de l'école normale supérieure, 2001

- [MUET99] Muet, Florence.- Services et revues électroniques dans l'enseignement supérieur : synthèses de quelques enquêtes récentes sur les usages, in : Bulletin des Bibliothèques de France, 1999, Vol.44, No.5, pp. 18 - 23

- [SANV01] Sanville, Thomas J.- Use of electronic journals of OhioLINK's electronic journal centre. http://www.ifla.org/IV/IFLA67/papers/118-141e.pdf

- [VAND00] Van Dooren, Bruno.- Rapport Van Dooren : Bibliothèques universitaires et nouvelles technologies. June 1999. www.education.gouv.fr/rapport

- $\quad$ OKRE00] Okret, Christine, «La numérisation des thèses en France : pour une meilleure valorisation de la recherche scientifique française », Liber quarterly, No.10, pp.26-30, 2000

- [PERO02] Perol-Isaacson, Dominique, Lamy-Faure, Catherine, Sabatier, Isabelle, Entre tradition et innovation : les pratiques documentaires des chercheurs en économie gestion, pp. 199-205, in : Les chercheurs et la documentation numérique : nouveaux services et usages, sous la direction de Ghislaine Chartron, éditions du cercle de la librairie, 2002, $268 \mathrm{p}$.

- [PERN02] Pernoo-Bécache, Marianne. - l'émergence des études littéraires françaises sur Internet: une dynamique sans retour?, pp. 211-227, in: : Les chercheurs et la documentation numérique : nouveaux services et usages, sous la direction de Ghislaine Chartron, éditions du cercle de la librairie, 2002, 268 p.

- [RUSS96] Russon, David, Campbell, Robert, «Access to journals : a joint publisher/librarian analysis », $\log o s$, No.7/2, 1996 